\title{
IMPROVEMENT ENVIRONMENTAL PERFORMANCE ENTERPRISES BY USING ENVIRONMENTAL STRATEGY RESOURCE EFFICIENT AND CLEANER PRODUCTION
}

\section{ПОЛІПШЕННЯ ПОКАЗНИКІВ ЕКОЛОГІЧНОСТІ ПІДПРИЕМСТВ ЗАСТОСУВАННЯМ ЕКОЛОГІЧНОЇ СТРАТЕГІЇ РЕСУРСОЕФЕКТИВНОГО ТА ЧИСТОГО ВИРОБНИЦТВА}

\author{
Yevheniia S. Tsiuman \\ y.tsiuman@ntu.edu.ua \\ ORCID: 0000-0001-9677-4411 \\ Vadym I. Ziuziun \\ v.ziuziun@ntu.edu.ua \\ ORCID: 0000-0001-6566-8798
}

\author{
С. С. Цюман, \\ канд. екон. наук \\ В. І. Зюзюн, \\ канд. техн. наук, доцент
}

\author{
National Transport University, Kyiv \\ Національний транспортний університет, м. Київ
}

\begin{abstract}
The high level of nature use and the exhaustibility a lot of natural resources create difficulties in further providing of society with material goods. This situation contradicts the key task of the nature use economy. The high resource intensity and the large amount of waste from enterprises require to measures implementation for enterprise eco-modernization.

Purpose of study is presentation of approaches to enterprises eco-modernization using the environmental strategy of resource efficient and clean production. The strategy is aimed to improve the indicators of nature use and enterprises environmental friendliness, reduce the environmental risks and the burden on the environment.

Method is based on the study of relationships in the "production - environment" system and the eco-modernization measures implementation stages. It is suggested the six groups of evaluation indicators and additional environmental performance of enterprise production and technological processes. The additional performances are the coefficients of isolation, turnover of natural resources and purity, the category (degree) of production hazard and environmental criteria. Results. Ecological and economic analysis is one of the assessment tools for enterprise environmental sustainability. It is aimed to study the complex of relationships in the "production - environment" system. Use of this tool allows to make the enterprise potential assessment and the identification of enterprise modernization opportunities.

Scientific novelty is optimal selection of assessing indicators for the level of nature use and enterprise environmental friendliness to implement the resource efficient and more clean production in accordance with the circular economy principles.

Practical importance. The evaluation and analysis of the proposed indicators allow the comprehensive and more complete assessment of the nature use and enterprise environmental friendliness level to search for optimal resource efficient solutions.
\end{abstract}

Key words: nature use; pollution; ecological and economic analysis; circular economy; resource efficient and clean production; environmental friendliness.

Анотація. Високий рівень природокористування та вичерпність багатьох природних ресурсів створюють труднощі для подальшого забезпечення суспільства матеріальними благами, що суперечить ключовому завданню економіки природокористування. Висока ресурсоємність та відходомісткість підприємств спонукають до впровадження заходів із їх екомодернізації.

Мета полягає у висвітленні підходів щодо екомодернізації підприємств шляхом застосування екологічної стратегії ресурсоефективного та чистого виробництва, спрямованої на поліпшення показників природокористування та екологічності підприємств, зниження екологічних ризиків та зменшення навантаження на навколишнє природне середовище.

Методика. На основі здійсненого вивчення взаємозв'язків в системі «виробництво - навколишнє природне середовище» та етапів впровадження заходів з екомодернізації визначено, що методику доречно розглядати за 
6 групами спеціальних індикаторів, перелік яких наведено в роботі, та додатковими показниками екологічності виробничих і технологічних процесів суб'єктів господарювання (коефіцієнти замкненості, колообігу природних ресурсів та чистоти, категорія (ступінь) небезпечності виробництва та критерій екологічності).

Результати. Використання одного з інструментів оцінювання екологічної стійкості підприємств - еколого-економічного аналізу, який спрямований на вивчення комплексу взаємозв'язків в системі «виробництво - навколишнє природне середовище», дозволяє здійснити дослідження потенціалу та виявлення можливостей модернізації підприємства.

Наукова новизна полягає в оптимальному підборі показників оцінювання рівня природокористування та екологічності підприємства з метою впровадження заходів із ресурсоефективних та більш чистих виробництв відповідно до принципів циркулярної економіки.

Практична значимість. Оцінювання та аналіз запропонованих показників дозволяе комплексно й повно оцінити рівень природокористування, екологічності підприємства для пошуку оптимальних ресурсоефективних рішень.

Ключові слова: природокористування; забруднення; еколого-економічний аналіз; циркулярна економіка; ресурсоефективне й чисте виробництво; екологічність.

\section{ПОСТАНОВКА ЗАДАЧІ}

Високе ресурсоспоживання та збиткоємність більшості українських підприємств, зумовлені високим рівнем зносу основних засобів та відсутністю дієвої політики управління, спонукають до пошуку раціоналізації управлінських рішень, орієнтованих на пріоритетність підвищення екологічності всіх процесів діяльності підприємства та ефективне еколого-економічне управління. Ефективне еколого-економічне управління передбачає постійне виконання еколого-економічного аналізу, пошуку, обгрунтування та координації ресурсоефективних рішень, моніторингу еколого-економічної ефективності впроваджених заходів, контролю діяльності, здійснюваної відповідно до прийнятої «Стратегії розвитку», та подальшого планування ресурсоефективної та малоабо безвідходної діяльності підприємства.

\section{АНАЛІЗ ОСТАННІХ ДОСЛІДЖЕНЬ І ПУБЛІКАЦЙ}

Питання підвищення екологічної стійкості підприємств відповідно до принципів циркулярної економіки не $\epsilon$ новим: подібні моделі застосовувалися раніше та застосовуються сьогодні у високорозвинених країнах, тому що вони є достатньо обгрунтованими, відповідають стратегіям та цілям сталого розвитку. Питаннями пошуку і впровадження ресурсоефективних рішень щодо зниження рівня природокористування та ефективного управління відходами, їх рециклінгу та використання у якості вторинної сировини займаються такі українські та закордонні дослідники, як А. Війкман, К. Сконберг [1], Г. Швиданенко, Д. Матукова, Л. Мельник [2], Н. Нестерова [3], Р. Малишева [4], М. Балджи [5], О. Щербина [6], Г. Савицька [9], Л. Булгакова, Л. Костилєва, Л. Попова, П. Рєпін, М. Джумабаєва [10] та інші.

ВІДОКРЕМЛЕННЯ НЕ ВИРІШЕНИХ РАНІШЕ ЧАСТИН ЗАГАЛЬНОЇ ПРОБЛЕМИ

Попри велику кількість досліджень, питання екорозвитку підприємств на принципах циркулярної економіки та реалізації заходів із впровадження ресурсоефективних, більш чистих виробництв в нашій країні $\epsilon$ гостро актуальним, тому що немає дієвого і єдиного механізму, що дозволив би активізувати екомодернізацію суб'єктів господарювання, забезпечивши таким чином процеси сталого розвитку, поліпшення природокористування та зниження шкодомісткості українських виробництв. Орієнтуючись на розвиток підприємства, суб' єкти господарювання, зокрема, націлені на швидке отримання економічного ефекту, незважаючи на те, що економічним ефектом з часом стане кумулятивний екологічний ефект за рахунок зменшення збитків. Таким чином, важливо продовжувати дослідження в даному напрямі і шукати нові економічні та організаційні інструменти сталого розвитку підприємств, орієнтовані на зменшення ресурсоємності та підвищення збалансованості природокористування.

\section{МЕТА ДОСЛІДЖЕННЯ}

Авторами поставлено за мету висвітлення підходів екомодернізації підприємств шляхом застосування стратегії ресурсоефективного та чистого виробництва, підбір методики оцінювання показників природокористування та екологічності підприємств для пошуку рішень щодо зниження екологічних ризиків та зменшення навантаження на навколишнє природне середовище.

\section{МЕТОДИ, ОБ'СКТ ТА ПРЕДМЕТ ДОСЛІДЖЕННЯ}

Вирішення визначених в статті завдань здійснено шляхом комплексного використання методів загальнонаукового та прикладного характеру, зокрема структурного, системного аналізу та синтезу. Об'єктом дослідження є процес формування системи показників оцінювання рівня природокористування та екологізації підприємств.

Предметом дослідження є теоретико-методичний інструментарій з формування складових частин стратегії із ресурсоефективного та чистого виробництва.

\section{ОСНОВНИЙ МАТЕРІАЛ}

За прогнозами експертів, до 2050 року світова економіка зросте у чотири рази, а населення світу 


\section{ТЕХНОЛОГІЇ ЗАХИСТУ НАВКОЛИШНЬОГО СЕРЕДОВИЩА №2 2021}

збільшиться з сьогоднішніх 7,3 мільярдів приблизно до 10 мільярдів. У нещодавньому звіті ООН про населення, представленому у липні 2015 року, наводиться переглянутий (у більшу сторону) варіант попередніх прогнозів щодо населення та передбачається, що на початку наступного століття населення світу сягне мінімум 11 мільярдів людей. У звіті ОЕСР «Екологічні перспективи до 2050 року» зазначено додаткове навантаження на матеріальні та енергетичні ресурси Землі і навколишнє середовище, яке може бути викликане збільшенням чисельності населення. Зростаюче населення з підвищеним середнім рівнем доходу потребуватиме більше продуктів харчування, промислових товарів, більше енергії і води. Це створює величезні проблеми для сталого економічного та екологічного розвитку i, зокрема, для ефективнішого використання ресурсів [1].

Л. Мельник стверджував, що економічна система вичерпує ресурси природних систем планети і підходить до усвідомлення об'єктивної необхідності переходу до нових форм взаємин із природою, що зумовлені неминучістю реформування економічних систем і суспільних відносин [2]. Таким чином, для реформування економічних систем і суспільних відносин актуальності набуває активізація сталого розвитку суб'єктів господарювання на принципах циркулярної економіки, що спрямовані на зниження рівня природокористування, формування дієвої системи управління відходами на підприємствах та організацію впровадження технологій рециклінгу.

H.I. Нестерова визначає, що природокористування - це об'єктивно зумовлений процес залучення людиною природних ресурсів до виробничої та невиробничої діяльності, їх відтворення та охорона. У сучасних умовах науково-технічного й соціального прогресу це поняття стає дуже містким та не завжди однозначно розуміється [3, с. 662].

Якщо розглядати природокористування як процес, діяльність, яку можна дослідити, необхідно зауважити, що рівень природокористування визначається раціональністю.

Н.Р. Малишева визначає, що однією з ознак раціональності природокористування, що інколи вказується в літературі, є його комплексність. Комплексність у природокористуванні - це використання природного ресурсу в спосіб, що дозволяє максимально задіяти всі його корисні властивості з метою задоволення різнобічних потреб (як комунально-побутових, так i економічних (господарських) чи інших (екологічних, естетичних, рекреаційних)) [4].

М.Д. Балджи зазначає, що раціональність залежить від всебічного вивчення природних ресурсів, яке полягає у:

- визначенні оптимальних норм користування природними ресурсами;

- обгрунтуванні найефективнішого розміщення галузей виробництва та пропозицій щодо господарювання;

- еколого-економічному оцінюванні природних ресурсів;

- розробці регіональних систем господарювання,

- прогнозуванні та оцінці наслідків господарської діяльності тощо [5].

Прикладом раціонального природокористування в екології вважається безвідходне виробництво, де повністю використовуються відходи виробництва, внаслідок чого знижується витрата сировини, а забруднення довкілля зводиться до мінімуму. Одним із видів такого виробництва є багаторазове використання в технологічному процесі води, взятої 3 річок, озер, бурових свердловин. Ця вода очищується та знову бере участь у виробничому процесі $[6$, с. 258]. Отже, єдиним способом досягнення сталого розвитку підприємств, раціональності природокористування $€$ розвиток виробництв на принципах циркулярної економіки (економіки замкненого циклу). Основним завданням циркулярної економіки $\epsilon$ найбільш широке використання відновлювальних ресурсів та перехід до безвідходного виробництва. Багаторазове використання одного і того ж матеріалу як сировини допоможе мінімізувати економічні збитки навколишнього середовища.

Основу циркулярної економіки становлять:

- ресурсоефективне та чисте виробництво (далі - РЕЧВ);

- кращий дизайн продукції (вироби 3 більшим терміном використання, можливістю ремонту, демонтажу, повторного використання, перевиготовлення);

- управління відходами (пріоритетність поводження 3 відходами (обробка для повторного використання - рециклінг, обробка для відновлення енергії - видалення);

- рециклінг (використання вторинної сировини, ресурсів).

На рисунку 1 представлено етапи запровадження РЕЧВ, серед яких перші п'ять етапів $є$ етапами впровадження, а шостий - «постфактум».

РЕЧВ - комплексна й послідовна екологічна стратегія для застосування у виробничих процесах, спрямована на підвищення економічної ефективності виробництва, зниження виробничих ризиків для населення та зменшення навантаження на навколишнє природне середовище [7].

Розглянемо докладніше представлені етапи.

1етап - ознайомлення з об'єктом, виробничими дільницями, характеристиками та станом устаткування, умовами зберігання та використання ресурсів, сировини, виконання необхідних вимірювань (вимірювань масових концентрацій забруднюючих речовин у викидах стаціонарних, пересувних джерел; масових концентрацій забруднюючих речовин в атмосферному повітрі, повітрі приміщень; 
масових забруднюючих речовин в поверхневих, підземних, стічних, зворотних дренажних водах; масових концентрацій нафтопродуктів у воді, грунтах; вимірювання еквівалентного та максимального рівнів шуму), вивчення відомостей первинного обліку та статистичної звітності підприємства в галузі природокористування, відомостей бухгалтерського обліку та звітності [8]. Необхідно зауважити, що рішення щодо екорозвитку підприємств, здійснення екополітики приймає керівництво підприємства, тому повинна бути проведена зустріч 3 керівни- цтвом, топменеджерами, менеджерами виробничих підрозділів, обов'язком яких буде підтримання системи екологічного менеджменту.

2 етап - попереднє оцінювання впливу на навколишнє середовище всіх видів діяльності, процесів та можливостей, перспектив суб'єкту господарювання щодо інноваційного екорозвитку, а саме дослідження динаміки собівартості і рентабельності окремих видів продукції, оцінювання фінансового стану, аналіз екологічної діяльності (використання та забруднення природних ресурсів, плата

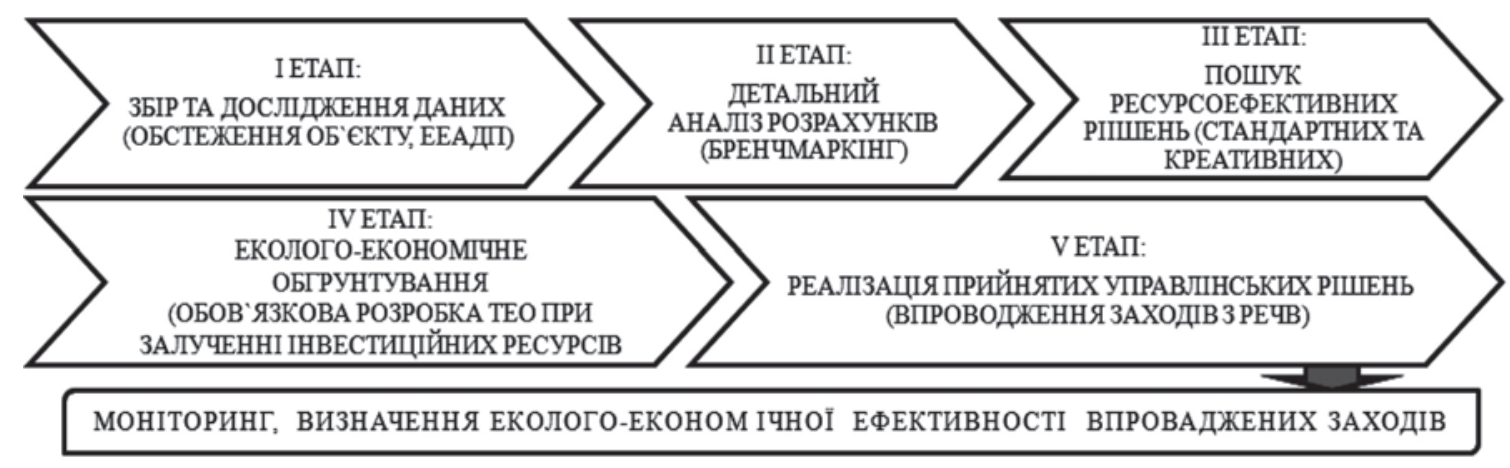

Рис. 1. Етапи впровадження заходів РЕЧВ

Джерело: розроблено авторами за [7-9]

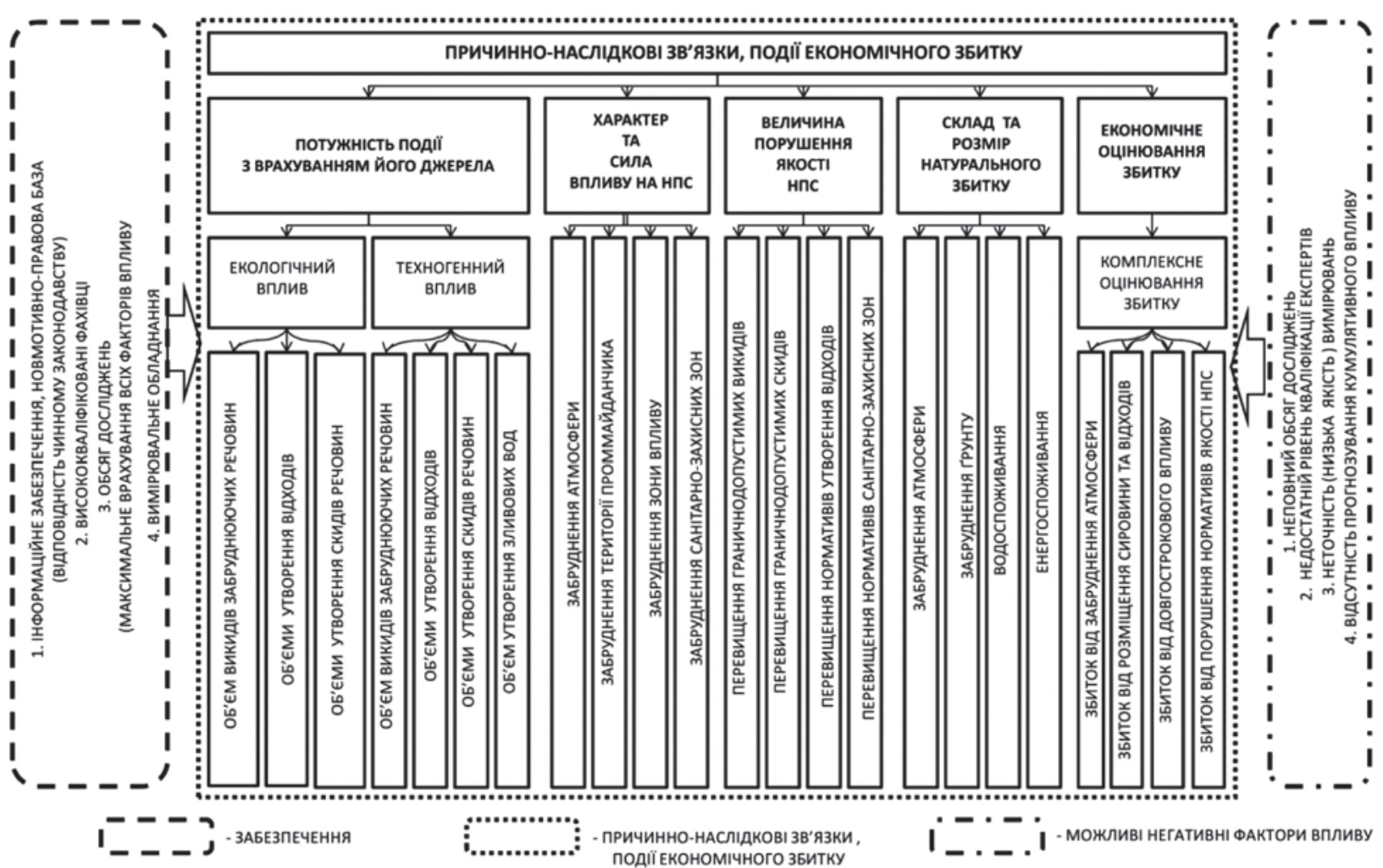

Рис. 2. Аналітична схема структури прогнозованого збитку

Джерело: розроблено за [10] 


\section{ТЕХНОЛОГІЇ ЗАХИСТУ НАВКОЛИШНЬОГО СЕРЕДОВИЩА №2 2021}

за забруднення) [9]. 3 метою оцінювання прогнозованого збитку під час дослідження здійснюють вивчення комплексу взаємозв'язків в системі «виробництво - навколишнє природне середовище», аналіз причинно-наслідкових відносин економічного збитку підприємства [10] (рис. 2). Оцінювання природоємності (рівня природокористування) та екологічності підприємства доречно проводити на основі системи показників загального, питомого природокористування та забруднення природних комплексів. До таких показників слід віднести ресурсомісткість, енергоємність, землеємність, збиткоємність, екоємність (відходоємність, вуглецевоємність) [11; 12] та додаткові показники екологічності виробничих, технологічних процесів суб' єктів господарювання (коефіцієнти замкненості й колообігу природних ресурсів та чистоти, категорію (ступінь) небезпечності виробництва та критерій екологічності). При здійсненні аналізу природоспоживання підприємства доречно використовувати бренчмаркінг - порівняльний аналіз на основі еталонних показників, що $\epsilon$ процесом визначення, розуміння та адаптації наявних прикладів ефективного функціонування підприємства з метою поліпшення власної роботи.

3 етап - етап пошуку РЕЧВ-заходів, спрямованих на зниження рівня природокористування (мінімізацію ресурсоспоживання) та підвищення екологічності виробництва (зниження антропогенного навантаження). РЕЧВ-заходи поділяються на стандартні та креативні. Для пошуку креативних заходів доречно застосовувати метод мозкового штурму.

4 етап - етап розроблення проєкту, техніко-економічного обгрунтування обраних РЕЧВ-заходів, а також прогнозування економічної, екологічної та соціальної ефективності їхнього впровадження. 3 метою оцінювання показників ефективності застосовують математичні методи (математичний апарат). До основних показників ефективності інноваційних проєктів найчастіше відносять норму прибутку, період окупності, чистий приведений дохід, індекс рентабельності (прибутковості), внутрішню норму доходності.

Відповідно до результатів проведеного дослідження з ефективності інноваційного розвитку підприємства 3 впровадженням РЕЧВ-заходів керівництво підприємства повинно прийняти рішення підтримання або відхилення політики з еколого-економічного розвитку. Стратегію екологічного розвитку підприємства розробляють на довгостроковий період.

Зауважимо, що перші два етапи є основними етапами здійснення еколого-економічного аналізу діяльності підприємства (ЕЕАДП) (рис. 3).

5 етап - етап впровадження обраних заходів на основі прийнятих управлінських рішень. До найпоширеніших РЕЧВ-заходів відносять заходи, що:
1) знижують, оптимізують рівень ресурсоспоживання, зокрема: енергоспоживання (теплового, електричного і паливного), пов'язаного з виробництвом продукції, 3 господарчими, комунальними потребами підприємства, 3 утилізацією відходів; водоспоживання, пов'язаного 3 виробництвом продукції, господарчими та комунальними потребами підприємства; споживання земельних ресурсів, пов'язаного 3 нераціональним розміщенням сировинних ресурсів, відходів виробництва; споживання інших ресурсів (сировинних); 2) мінімізують вплив на довкілля: зменшення відходів, викидів та скидів; 3) підвищують добробут людей: зниження ризику для населення і навколишнього середовища.

6 етап - етап «постфактум» - проведення моніторингу (оцінювання) еколого-економічної ефективності впровадження РЕЧВ-заходів з метою своєчасного виявлення відхилень, що дозволить вчасно внести корективи. Необхідно зауважити, що з метою проведення належної екологічної політики та сталого розвитку підприємства у майбутньому необхідною умовою є застосування процедур моніторингу, контрою на постійній основі.

Для експрес-оцінювання (поствпровадження) еколого-економічної ефективності природоохоронних заходів використовують показник чистого економічного ефекту (перевищення середньорічного народногосподарського результату над приведеними річними витратами (різниця між економічним результатом природоохоронних заходів та витратами на їхню реалізацію)), показник періоду окупності.

\section{ОБГОВОРЕННЯ ОТРИМАНИХ РЕЗУЛЬТАТІВ}

Відповідно до результатів виконаного ЕЕАДП на основі запропонованих показників визначеного потенціалу та можливостей модернізації підприємства обирають стратегію розвитку підприємства, інструменти для його екомодернізації та подальшого еколого-економічного управління. Обрані заходи, що спрямовані на належне господарювання, можуть передбачати не тільки модернізацію чи оновлення основних засобів виробництва, застосування ресурсозберігаючих технологій. Вони спрямовані також на таку роботу: технологічні зміни; переробку, заміну або повторне використання ресурсів, сировини, відходів; використання вторинних енергетичних ресурсів, відновлювальних джерел енергії; модифікацію продукції та виробництво супутньої. Орієнтуючись на розвиток підприємства, відповідно до прийнятої стратегії РЕЧВ при обранні ресурсів, сировини відбувається зміна постачальників. Отже, необхідно зазначити, що при впровадженні екологічної стратегії розвитку на підприємстві зміни будуть відбуватися на всіх етапах виробництва продукції та управління підприємством. 


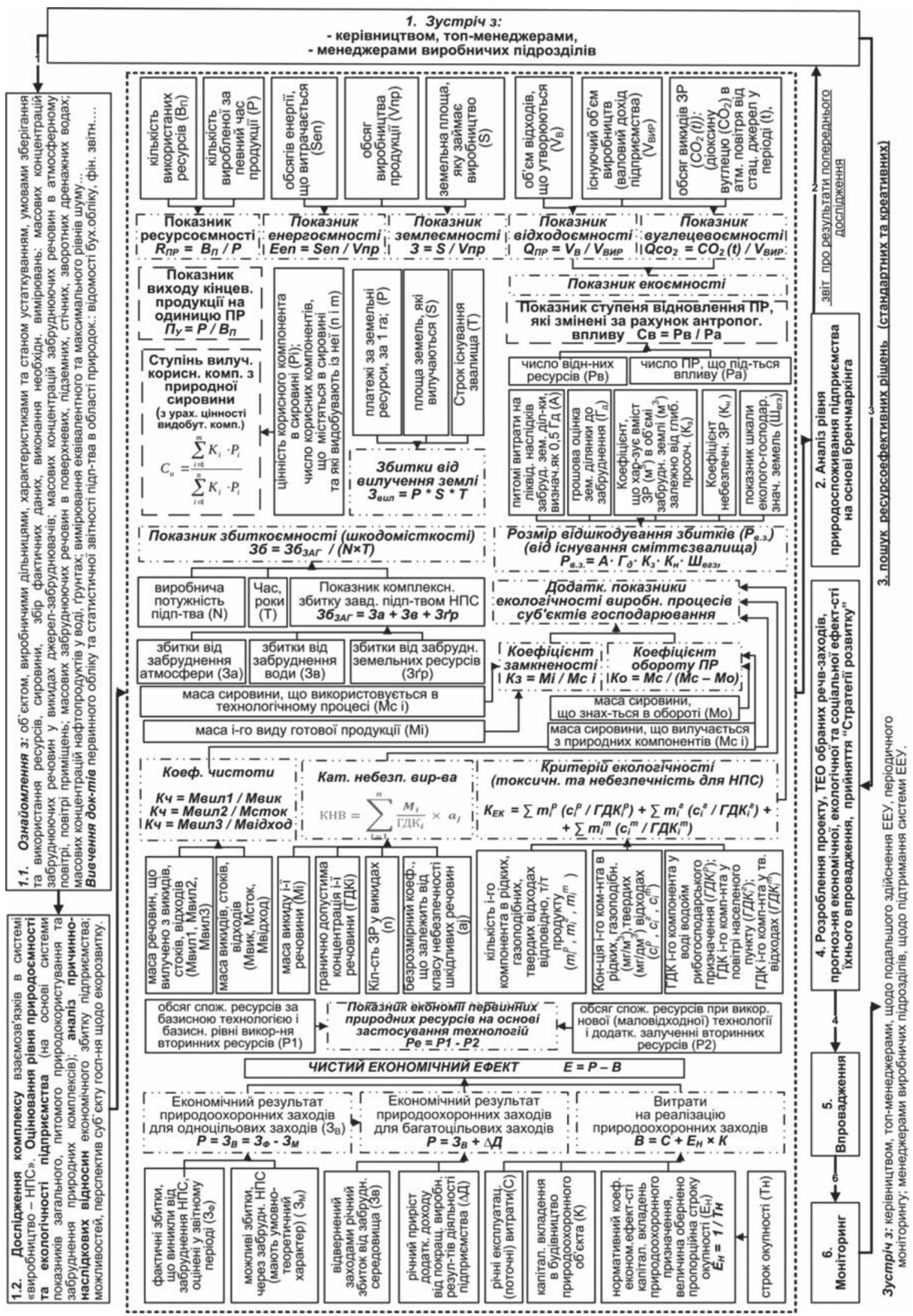

Рис. 3. Алгоритм здійснення екомодернізації підприємств, спрямованої на поліпшення природокористування шляхом застосування стратегії РЕЧВ

Джерело: розроблено авторами 


\section{ТЕХНОЛОГІЇ ЗАХИСТУ НАВКОЛИШНЬОГО СЕРЕДОВИЩА №2ロ 2021}

\section{ВИСНОВКИ}

На основі ретельно проведеного екологоекономічного аналізу та впровадження підходів щодо екомодернізації підприємств відповідно до обраної екологічної стратегії із ресурсоефективного та чистого виробництва можливо досягти поліпшення показників природокористування та екологічності, зниження екологічних ризиків та зменшення навантаження на навколишнє природне середовище, налагодити сталий розвиток підприємства.

При належній підтримці з боку держави інноваційної екомодернізації підприємств, а також при достатньому інституційному та фінансовому забезпеченні можливо досягти збереження природноресурсного потенціалу не тільки окремих регіонів, а й країни в цілому, що сприятиме їі сталому економічному зростанню та соціальному розвитку.

\section{REFERENCES}

[1] Vijkman, A. \& Skonberg, K. (2017). Cyrkuljarna ekonomika ta perevaghy dlja suspiljstva. Zvit pro doslidzhennja na vymoghu Rymsjkogho klubu za pidtrymky Fondu MAVA [Circular economy and benefits for society]. 54 p. Retrieved from: http://www.clubofrome.org.ua/wp-content/uploads/2017/08/The-Circular-Economy-CoR_UA-2.pdf.

[2] Shvydanenko H. O., Matukova D.H. (2014). Udoskonalennya mekhanizmu derzhavnoho rehulyuvannya protsesiv ekolohizatsiyi hirnycho-zbahachuval'nykh pidpryyemstv. [Improvement of state regulation of greening mining enterprises]. Efektyvna ekonomika, no 2. Retrieved from: URL: http://www.economy.nayka.com.ua/?op=1\&z=2801.

[3] Nesterova N. I. (2019). Pryntsyp ratsional'noho vykorystannya pryrodnykh resursiv v ekolohichnomu pravi Ukrayiny [Principle of rational use of natural resources in environmental law of Ukraine]. Kharkiv, 203 p. Retrieved from: https:// dspace.nlu.edu.ua/handle/123456789/16542.

[4] (2018). Velyka ukrayinska yurydychna entsyklopediya U 20 t, T. 14 [Great Ukrainian legal encyclopedia]. Kharkiv. Ekolohichne pravo, $776 \mathrm{p}$.

[5] Baldzhy M.D. (2010) Orhanizatsiyno-ekonomichni zasady kompleksnoho pryrodokorystuvannya na rehional'nomu rivni [Organizational and economic principles of integrated environmental management at the regional level]. Odesa, Atlant, $500 \mathrm{p}$.

[6] Shcherbyna O. M. (2010). Deyaki aspekty pravovoho rehulyuvannya vykorystannya pryrodnykh resursiv. Problemy natsional'noyi derzhavnosti [Some aspects of legal regulation of the use of natural resources. Problems of national statehood]. materialy mizhnar. nauk. konf. Odes. nats. un-t im. I. I. Mechnykova, Ukr. in-t sots.-prav. doslidzh. Odesa. Astroprynt, pp. 257-260.

[7] (2021) Materialy navchal'nogo onlajn-kursu «Resursoefektyvne ta chyste vyrobnyctvo»: vebsait [Materials of the online training course «Resource efficient and clean production»: website]. Retrived from: http://www.recpc.org/recp-course-ua.

[8] (2021). We submit annual statistical reports: all about changes in reporting forms for 2020 and recommendations for filling [Zdajemo richnu statystychnu zvitnist': vse pro zminy po formah zvitnosti za 2020 rik ta rekomendacii' shhodo zapovnennja]. Shhomisjachnyj specializovanyj zhurnal v galuzi ekologii' «Ekologija pidpryjemstva». TOV «Ekobiznes grup», no. 2, pp. 13-19.

[9] Savyc'ka, G. V. (2008). Analiz finansovo-gospodars'koi' dijal'nosti [Analysis of financial and economic activities]. Infa-M, 467 p.

[10] Bulhakova L.M., Kostylyeva L.N., Popova L.V., Repin P.S., Dzhumabayeva M. (2013) Kompleksna otsinka ekolohoekonomichnykh ryzykyv pidpryyemstva po pererobtsi vidkhodiv.[Comprehensive assessment of the environmental and economic risks of a waste processing enterprise]. Sovryemyennyye problyemy nauky y obrazovaniya. Ekonomichyeskiye nauki. no. 6. Retrieved from: https://www.science-education.ru/ru/article/view?id=11116.

[11] (2019) Metodychni rekomendatsiyi shchodo rozrakhunku pokaznykiv resursoyemnosti valovoho vnutrishn'oho produktu na rivni natsional'noyi ekonomiky za osnovnymy hrupamy resursiv [Methodical recommendations for calculating the resource intensity of gross domestic product at the level of the national economy by main groups of resources]. Nakaz Ministerstva ekonomichnoho rozvytku i torhivli Ukrayiny, no. 965. Retrieved from: https://ips.ligazakon.net/document/ME190622.

[12] (2020) Metodyka rozrakhunku rozmiriv vidshkoduvannya zbytkiv, yaki zapodiyani derzhavi v rezul'tati nadnormatyvnykh vykydiv zabrudnyuyuchykh rechovyn $\mathrm{v}$ atmosferne povitrya [Methodic of calculating the amount of compensation for damages caused to the state as a result of excessive emissions of pollutants into the atmosphere]. Nakaz Ministerstva enerhetyky ta zakhystu dovkillya Ukrayiny,. no. 277. Retrieved from: https://zakon.rada.gov.ua/laws/show/z0414-20.

\section{СПИСОК ВИКОРИСТАНОЇ ЛІТЕРАТУРИ}

[1] Війкман А., Сконберг К. (2017). Циркулярна економіка та переваги для суспільства. Явні переможці в області робочих місць та клімату в економіці, заснованій на відновлюваній енергії та ресурсоефективності. Дослідження стосовно Чеської Республіки та Польщі. URL: http://www.clubofrome.org.ua/wpcontent/uploads/2017/08/The-CircularEconomy-CoR_UA-2.pdf (дата звернення: 17.04.2021).

[2] Швиданенко Г.О., Матукова Д.Г. (2014). Удосконалення механізму державного регулювання процесів екологізації гірничо-збагачувальних підприємств. Ефективна економіка. № 2. URL: http://www.economy.nayka.com. ua/?op=1\&z=2801 (дата звернення: 16.04.2021).

[3] Нестерова Н.I. (2019). Принцип раціонального використання природних ресурсів в екологічному праві України : дис. ... канд. юрид. наук : 12.00.06. Харків. 203 с. URL: https://dspace.nlu.edu.ua/handle/123456789/16542 (дата звернення: 26.04.2021). 
[4] (2018). Велика українська юридична енциклопедія : у 20 т. Т. 14: Екологічне право / редкол. : Ю.С. Шемшученко (голова), А.П. Гетьман (заст. голови) та ін. ; Нац. акад. прав. наук України, Ін-т держави і права ім. В.М. Корецького НАН України, Нац. юрид. ун-т ім. Ярослава Мудрого. 776 с.

[5] Балджи М.Д. (2010). Організаційно-економічні засади комплексного природокористування на регіональному рівні : монографія. Одеса : Атлант. 500 с.

[6] Щербина О.М. (2010). Деякі аспекти правового регулювання використання природних ресурсів. Проблеми національної державності : матеріали міжнар. наук. конф. пам’яті д-ра юрид. наук, проф. Стрельцова Льва Михайловича (1918-1979), 26 берез. 2010 р. М-во освіти і науки України ; Одес. нац. ун-т ім. І.І. Мечникова, Укр. ін-т соц.прав. дослідж. Одеса : Астропринт. С. 257-260.

[7] Ресурсоефективне та чисте виробництво : матеріали навчального онлайн-курсу. 2021. URL: http://www.recpc.org/ recp-course-ua (дата звернення: 11.03.2021).

[8] Здаємо річну статистичну звітність: все про зміни по формах звітності за 2020 рік та рекомендації щодо заповнення. Екологія підприємства : щзомісячний спеціалізований журнал в галузі екології. ТОВ «Екобізнес груп». 2021. № 2. C. 13-19.

[9] Савицька Г.В. (2008). Аналіз фінансово-господарської діяльності : навч. посіб. 4-те вид., випр. и доп. Москва : Инфра-М. 467 с.

[10] Булгакова Л.М., Костылева Л.Н., Попова Л.В., Репин П.С., Джумабаева М. (2013). Комплексная оценка экологоэкономических рисков предприятия по переработке отходов. Современные проблемы науки и образования. Серия «Экономические науки». 2013. № 6. URL: https://www.science-education.ru/ru/article/view?id=11116 (дата звернення: 17.04.2021).

[11] (2019). Методичні рекомендації щодо розрахунку показників ресурсоємності валового внутрішнього продукту на рівні національної економіки за основними групами ресурсів : затв. наказом Міністерства економічного розвитку і торгівлі України від 06 черв. 2019 р. № 965. URL : https:/ips.ligazakon.net/document/ME190622 (дата звернення: 17.04.2021).

[12] (2020). Методика розрахунку розмірів відшкодування збитків, які заподіяні державі в результаті наднормативних викидів забруднюючих речовин в атмосферне повітря : затв. наказом Міністерства енергетики та захисту довкілля України від 28 квіт. 2020 р. № 277. URL: https://zakon.rada.gov.ua/laws/show/z0414-20 (дата звернення: 19.04.2021).

(C) Цюман С. С., Зюзюн В. I. Дата надходження статті до редакції: 10.06.2021 Дата затвердження статті до друку: 24.06.2021 